\title{
Reform and innovation research of English majors Talent Training Mode of universities
}

\author{
Xia LI \\ Chengdu Polytechnic \\ Chengdu,Sichuan,610041 China
}

\begin{abstract}
With the formation of China's market economic system and because of the global economy integration and social informatization, the "scholastic" single-subject teaching model attached to foreign language and literature have difficult in meeting the social demand for English professionals. Social form of especially economic form determines the diversity of functions and educational goals of higher education. English, be regarded as a skill, support and tool, is not only dependent on language and literature, but also dependent on a variety of other applied professions in modern age. Constituting a complex architecture of knowledge is the trend and direction of English development of higher education undergraduate colleges.
\end{abstract}

\section{Keywords- Personnel training, model, innovation}

At present, China gradually steps into a knowledge economy, which not only promotes the social demand for various types of foreign talents, but also promotes the development of construction of the English Department and the entire discipline of English education. The cultivation of compound and applied talents has become the universities' imperative. English traditional training model has not kept pace with the new era, with the further intensified international competition. Social needs for the community college English major talent in quality, level, and comprehensive quality are put to a higher level, and the ability of application of its foreign language requires being more specific. Therefore, effectively training various forms, multi-level comprehensive English talents to adapt to the needs of society has become an important target of the current major colleges and universities.

\section{THE FRAME STRUCTURE OF ENGLISH MAJORS TALENTS TRAINING MODE}

The so-called "training mode" refers that colleges and universities, on the basis of the modern educational philosophy and ideological, according to the standards and quality of personnel training objectives, train personnel planned. The training program not only plans teaching content and reform program aiming to enable students to get better developments in ability, knowledge, and other aspects of the overall quality, but also includes ways and means to achieve the training objectives, and of course also covers teachers increased levels.

College English teaching should be based on needs of national economic construction and reform and opening up of the situation, continuously explores and improves the quality of foreign language teaching. As frontline teachers we continue to explore the training mode for English professionals, and try to find a new path. Based on the integration of "capacity-building and knowledge transfer, quality education and business cultivation, research and learning" personnel training ideas, and regarding the "student-centered" concept as a starting point for English, we design the training model for English major talents.

\section{OBJECTIVES OF ENGLISH MAJOR TALENTS TRAINING}

According to the new philosophy of education, objectives of English major talents training which are full of rich contents, specific and feasible to social requirements are established, as the following 4 aspects:

\section{A. Solid English skills}

English major trains specialized personnel. Students must have a high level of English language, and after graduation they can be competent in the field of foreign affairs of foreign trade, cultural exchanges and other challenging work. Oral and written English are necessary core competencies to do the work, which best reflects the English major advantages and characteristics.

\section{B. Reasonable knowledge structure}

Students should have a basic knowledge of history and culture of English-speaking countries, and understand the general development of Chinese and foreign humanities and social English. While studying Western thought and culture at the same time, students should deepen their understanding of Chinese culture and Chinese traditional thinking wisdom of experience, own the ability to use of a higher level bilingual intercultural communication, and gradually open up the western transition from bilingual to meet the globalization, localization requirements and common development. 


\section{Individualized development direction}

Under the premise of laying knowledge base, students according to their interests, potential and development objectives in the English discipline or interdisciplinary research direction choice, study more systematically related professional courses, and become research talents or applied talents having the ability to engage in international affairs.

\section{Excellent overall quality}

Students should establish a correct outlook on life, world and value, own psychological quality and strong ability to work, interpersonal communication skills, collaboration skills, organizational ability, care the community, apply what they have learnt, and have social responsibility, determine to be socialist builders and successors.

\section{NECESSITY OF UNIVERSITIES TALENTS TRAINING MODE REFORM}

\section{A. Structural contradictions caused by trade dislocation}

University graduation is completely a structural problem. The total number of college students is surplus. What leads to the employment of college graduates difficult? This is a very complex social phenomenon, both involves social employment mechanism, but higher education management system, colleges' own development and personnel training, as well as college students self-positioning, and in the era of college social forming too high psychological expectations of college students coasting and other issues. I think the key issue is training model problem.

\section{B. Dislocations of professional setting and demand is the main reason}

Talents grow up out of the study and practice, teaching practice and eventually accept the social practice test. Promoting economic and social development is the starting point and destination to personnel training. Human resources development must be coordinated with the economic and social development. In this regard, President $\mathrm{Hu}$ Jintao put forward the "Three Adaptation": First, promote the total number of talents compatible with national development objectives; second, adjust the talents structure to the comprehensive development of various undertakings; third, adjust the quality of talent to the economic social development. Our colleges and universities must see the countries' economic and social development needs as departure, and for the main battlefield of economic and social development, train a large number of high-level personnel urgently needed in social marketable. If the major setting and social needs dislocated, and even out of touch or the "herd" mentality, blind pursuit of economic interests mouth, regardless of whether their own qualification, professional and popular on the rush to what any professional setting, it will inevitably result in some areas in the short term, some industry professionals supply and demand imbalances. This is on the one hand trained people can not find suitable jobs, on the other hand some of the urgent need for personnel to work to find a suitable main reason for the phenomenon of talent

\section{ENGLISH MAJOR TALENTS TRAINING PROBLEMS}

China's opening up to promote the social demand for all kinds of foreign language class talent, on one hand requires these professionals to have a solid knowledge of English and a strong basic skills in English language, on the other hand requires them to have a basic knowledge of various fields. According to the Ministry of Education in 2000 promulgating the "Syllabus for English Majors', English curriculum can be divided into three categories: English professional knowledge, professional skills in English and relevant expertise. According to the outline of the new requirements, the requirements of contemporary English major talents training should not only focus on training solid basic skills, expand the ability for human knowledge and technological application of English majors, but also develop their ability to innovate, to think independently and the ability to acquire new knowledge and skills.

However, with the long-term English development of university on in our country, college English professional applied and compound talents training model also encountered many new problems during English teaching practice and there have been many new difficulties and challenges. Due to the constraints of English teaching conditions in different colleges and universities, school, teachers, and many other factors, the existing profession training mode mainly have the following problems.

\section{A. English professional training mode lags behind the development of society}

Since the 21st century, the community college English professional training requirements gradually increase. Comprehensive development of China's social and economic exchanges between countries increasingly becomes frequent, English majors are facing more challenges, and while also are provided new opportunities for their development and employment. However, the contemporary university English professional training mode relatively also lags behind. It is a basic training model of language teaching instead of excellent professional training and cultural knowledge, and knowing how to apply integrated local cultural, social, economic and other knowledge, English training model compound professionals.

\section{B. Courses and professional settings and practice does not comply}

Currently, the setting of college English teaching content in our country is traditional. The system is basically set up in accordance with the curriculum of English language texts. This traditional setting easily causes the divorce between teaching and practice, and there are very few opportunities for students to practice; some modern knowledge of technology and human. For example, natural sciences, and humanities elective knowledge are not included in the English teaching curricula; English curriculum lags behind the local economic development and social knowledge of the environment, ignoring the students' comprehensive knowledge and learning. Students are hard to adapt to the new requirements of contemporary English social development professionals. 


\section{Relatively single teaching method}

Generally speaking, self-learning should be the main type of English teaching methods and classroom teaching method supplemented. Butour professional English training model is still teaching method of teacher-centered classroom. This method is not from rigid teaching consider students' interest in learning the fundamental differences and divergent thinking, ignoring the interaction between teachers and students, resulting in a lack of adequate training of students analytical and problem-solving skills, the communication skills, creativity, organization and coordination, etc. terms of the overall quality is weak, so the lack of adequate training of personnel in the future competitiveness of the competitive recruitment process.

\section{Few practice for exchange students}

Currently, the majority of college English syllabus and lesson plans arrange students to go to other schools or school foreign exchange links. But during practice process, due to the impact of various factors, many practical projects are difficult to achieve and can not achieve the intended purpose. This leads many students to lose a lot of opportunities outside the school as well as to communicate in a foreign school.

\section{REFORM MEASURES}

\section{A. Establish goals of the English major construction}

Strengthen curriculum resources; ensure the course choosing outstanding teaching, conducting investigations through the use of a textbook every semester, feedback, timely comments on teachers and students understand the materials. Should pay close attention to the publication of new textbooks, the latest developments, update teaching materials as soon as possible, including the Foreign Language Department Reference Room in books, professional journals, foreign periodicals, newspapers and various foreign language dictionaries and other books, so that teachers and students can timely understand the various types of information professional information services for teaching and research, as it directly affects the quality of teaching to improve the implementation and teaching methods. Development of the times, books and periodicals are constantly changing demand for, further capital investment.

\section{B. Strengthen teaching conditions construction}

According to characteristics, we should continue to develop a number of professional schools, businesses or the company as a practice bases reflecting professional features and levels, the advanced, complete and practical, with practice, practice the value.

\section{Deepening teaching mode reform methods, means}

Teaching professional courses directly involves the ability of students in all aspects of training and improvement. English classroom teaching should be student-centered, teacher-led, and focus students' learning ability and research capabilities. Engage more task-centered forms of teaching and learning activities in teaching. At the same time strengthen the basic training, the use of heuristics, discussion, developmental research and teaching methods style, fully mobilize the enthusiasm of students, stimulate students' motivation to maximize learning for students to participate in the whole process, guide students to take the initiative active use of existing library materials and online information access to knowledge, and develop the capabilities of students to apply knowledge in the process.

\section{Promote combination of classroom teaching and student extracurricular activities learning and practice}

On the basis of extracurricular learning and activities practice stimulate students' interest in learning, students' ability to learn, comprehensive language skills, organizational skills, interpersonal skills, thinking skills and creativity. In the same attention to the development of student's personality, cultivate their spirit of cooperation.

\section{E. Strengthen the construction and development of business English courses}

Increase the proportion of business English courses to highlight relevance and applicability. Rely on business English jobs that require the ability, focus to teach business English basic knowledge and basic skills, increase business spoken, listening efforts to train the ability to enhance students' cross capacity for cultural exchange.

\section{FEATURES OF INNOVATIONS AND REFORM}

With the rapid development of the Chinese economy, the college English professional training model has been unable to meet the growing demand for professional applications in English culture is complex talent needs of the socialist market economy, but also the demands of the times. With the deepening of reform and opening up, the commodity economy is booming, training applications, complex English talent is the college English major new target. Therefore, the traditional English training model for reform and research universities are the inevitable result of the professional development of English and social needs.

Applied and compound college English professional training mode, emphasize cross-disciplinary integration and inter-penetration, stress people-oriented, it is necessary to have a solid foundation in English language, extensive knowledge and strong practical skills and theoretical knowledge; also to have a good psychological, ideological and moral quality and innovation.

Applications, complex college English professional training mode in accordance with the scientific concept of development, emphasizing facts, advance with the times, give full consideration to the actual clear conditions, due to the way the school system should, take complex, applicationoriented English personnel training, combined with the global economic development and market demand, develop distinctive, high-quality professionals, creating schools, professional characteristics.

In short, through the promotion of talent training mode reform and innovation, student enthusiasm of learning, initiative can be mobilized thus to form the hard work and 
good style of progress, promote the improvement of the overall quality of students' creative spirit and practical ability and personality in favor development of. By promoting personnel training mode reform and innovation, it can deepen the educational reform, improve the quality of education and quality of personnel training, so as to achieve good educational and social benefits.

\section{REFERENCES}

[1] Songlin Shan. Reform and Research College English Professional Training Mode [J]. English Square (academic),2012,08:99-101.

[2] Chen Shan. Universities English curriculum reform and set [D]. Shanghai International Studies University, 2012.

[3] Li Xuming. Teachers of English professional education and training of professional competence college students study [D]., Northwest Normal University, 2004.

[4] An Jinwei. Network Communication and New Media Professional Training Model Reform and Innovation Research [D]. Huazhong University of Science and Technology, 2012. 